\title{
潮流・海流発電に向けた津軽海峡の流況特性及び エネルギー賦存量に関する研究
}

\section{A Study on Flow Characteristics and Energy Potential in Tsugaru Strait Toward Tide and Ocean Current Power Generation}

\author{
本間翔希 ${ }^{1} \cdot$ 宮武 誠 $^{2} \cdot$ 猿渡亜由未 $^{3}$ \\ Syoki HONM A, M akoto MIYATA KE and Ayumi SA RUWATARI
}

\begin{abstract}
The water current characteristics and energy potential in Tsugaru Strait were investigated through field observation and numerical simulation. Using an ADCP, time series of multilayer velocity were measured during 31 days. As a result, the flow of Tsugaru Strait in the direction of southeast accompanied by periodic variations is constructed by combining the southeastward residual current to the tidal current in the direction of northwest-southeast. The ocean and tidal current in this strait were analyzed using MITgcm. The energy potential distribution estimated from the analysis results indicates that the most appropriate location of power generation is around the side of Shimokita Peninsula coast waters.
\end{abstract}

\section{1.はじめに}

近年の海洋再生エネルギーに脚光が浴びている中, 日 本周辺海域における潮流や海流の流況特性やエネルギー 賦存量を現地観測や数值解析により評価する研究が活発 化している（井内ら， 2011 ; 小牧ら，2013）。新エネル ギー・産業総合開発機構（NEDO）（2010）が推定した日 本周辺海域における潮流に関するエネルギー賦存量によ れば, 津軽海峡は他の海域の中でも高く推移することが 示されている。しかし，上記の検討は津軽海峡全域での 流速の代表值を用いた概略值であり，実際に津軽海峡を 流れる海流や潮流を利用して発電を行うにあたり，適地 選定や計画策定するためには，津軽海峡を流れる海流・ 潮流のより詳細な流況特性を把握することが重要であ る. 潮流・海流発電を念頭に置いた津軽海峡の流況特性 やエネルギー賦存量の推定に関しては, 既に数多くの研 究が行われており，例えば，猿渡ら（2013）は非静水圧 3次元モデルであるMIT General Circulation Model (MIT gcm, 例えばM arshallら，1997a，1997b）を用いて, 津軽海峡における潮流エネルギー・リソースに与える海 流の影響を考察している. しかし，これらの研究は数值 解析を主体とした検討に留まっており，実際に現地観測 を行い, その結果に基づき潮流や海流の流況特性を検討 した研究は少ない.

本研究は, 既往の研究から津軽海峡内で比較的流れの

\begin{tabular}{|c|c|c|}
\hline \multicolumn{2}{|l|}{1 学生会員 } & 函館工業高等専門学校専攻科環境システ \\
\hline 2 正会員 & 博 (工) & $\begin{array}{l}\text { 厶工学専攻 } \\
\text { 函館工業高等専門学校准教授社会基盤工 } \\
\text { 学科 }\end{array}$ \\
\hline 正会員 & 博 (工) & 北海道大学大学院工学研究院助教 \\
\hline
\end{tabular}

速い海域を選定し実施した流況観測から，観測期間中の 恒流と潮流の流況特性について解明する。 また，得られ た観測結果に基づき，猿渡ら（2013）と同様な方針のも と, MIT g cmによる津軽海峡の潮流と海流に関する数值 計算を行い, その再現性及び妥当性を検証する。 また, 観測期間中における津軽海峡全域の流況特性を把握する とともに，その結果に基づき推定したエネルギー賦存量 の平面分布の両面から, 津軽海峡における潮流・海流発 電の可能性について検討するものである.

\section{2. 津軽海峡における流況に関する現地観測}

潮流・海流発電を念頭に置いた津軽海峡の流況観測を 実施するにあたり，比較的流速の速い沿岸域を既往の文 献から把握する．猿渡・田島（2012）が行ったMIT gcmに よる津軽海峡の潮流最大流速分布によれば, 津軽海峡で 比較的流れの速い海域は, 狭窄水路となる白神岬一竜飛 崎間及び汐首岬 - 大間崎間になることが示されている. この結果に加え, 将来的に発電装置を設置する水深を勘 案して, 本研究は図-1のSt.1に示す汐首岬沿岸海域（水深 -25m地点）を対象として流況観測の位置を決定した.

観測は, 2013/3/18〜2013/4/18の31昼夜にわたり実施し, 計測項目はADCP（超音波式ドップラー流速計）による 多層流速・流向である. 当該海域の水深を上層, 中層, 下層の3層に分割し，観測期間中の各層における流速・ 流向を測定した．流況観測の諸元を表-1に示す．流速・ 流向データはサンプリング間隔を1秒とし，20分間の連 続計測を1時間間隔（定時）で行い収集した.

\section{3. 観測期間中における津軽海峡の流況特性}

図-2(a)，（b）及び（c）は，観測期間中に得られた上・ 


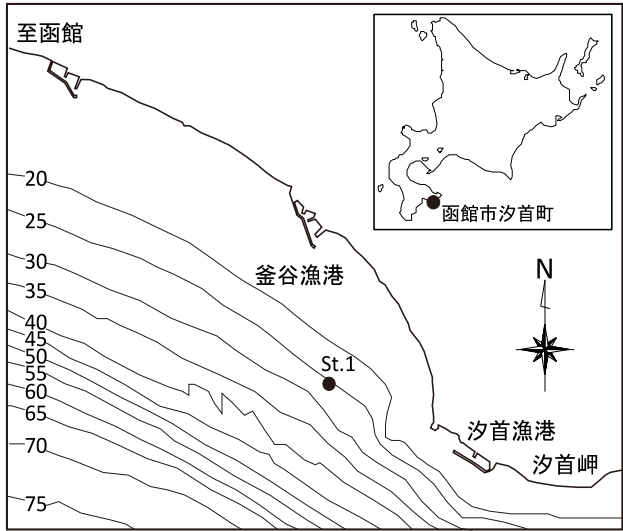

図-1＼cjkstart流況観測位置 (等深線の単位 : m)
表-1 流況観測の諸元

\begin{tabular}{|c|c|}
\hline 観測期間 & $\begin{array}{l}\text { 函館市汐首岬沖合約 } 800 \mathrm{~m} \text { （水深-25m） } \\
\text { 北緯 } 41^{\circ} 43^{\prime} 1.9^{\prime \prime} \quad \text { 東経 } 140^{\circ} 56^{\prime} 30.7^{\prime \prime}\end{array}$ \\
\hline 使用機器 & 2013年3月18日〜2013年4月18日の31亘夜間 \\
\hline 観測層 & $\begin{array}{l}\text { ADCP（超音波式ドップラー流速計） } \\
\text { 発信周波数 : } 300 \mathrm{kHz}\end{array}$ \\
\hline 測定間隔 & $\begin{array}{l}\text { 上層 : 海底から } 23.3 \mathrm{~m} \\
\text { 中層 : 海底から } 12.2 \mathrm{~m} \\
\text { 下層 : 海底から } 3.2 \mathrm{~m}\end{array}$ \\
\hline 測定時間 & 60 分 \\
\hline サンプリング間隔 & 20分 \\
\hline 観測位置 & 1秒 \\
\hline
\end{tabular}

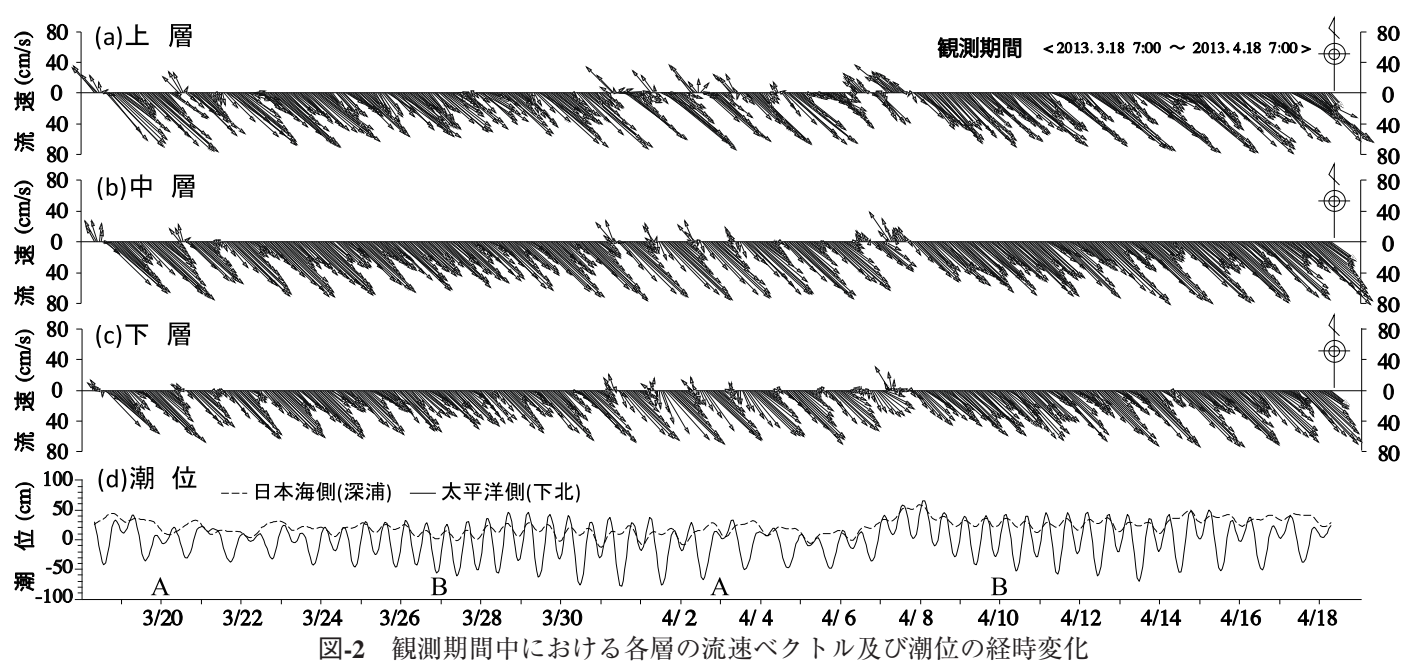

中・下層における流速べクトルの経時変化をそれぞれ示 す. 観測期間中における津軽海峡の流れは, 流速・流向 ともに水深方向にほぼ等しく分布し, 図-1で示した等深 線方向に沿って汐首岬に向かう南東方向の流れが, 全層 にわたり周期的な消長を伴いながら卓越する。観測期間 中における南東方向の流向発生頻度は70\%以上に達し, 観測期間内で測定された最大流速も卓越流向と同じ南東 方向で発生している。図-2(d) は，観測期間中における 気象庁による日本海側（深浦）及び太平洋側（下北）の 実測潮位の経時変化を示す。月齢により小潮となる図中 $\mathrm{A}$ の前後数日間は大潮となる図中Bの前後数日間に比較し て，前述した南東方向に向かう流れの周期的な消長が大 きくなる傾向にあり，特に南東方向の流れが弱まる時間 帯の一部では, 南東方向とは逆向きの北西方向へ転じる 流れが生じている。この月齢による潮汐の変化は, 津軽 海峡の周期的な流れの変動に影響を及ぼしているものと 推察される.
図-3は，上層で得られた北方流速及び東方流速にFFT によるスペクトル解析を行った結果を示す，パワースペ クトルは周期10秒以下の高周波成分で多少変動するもの の， 12時間及び24時間周期で明確なピークを示す．この ことから, 前出の図-2で見られた南東方向に周期的な消 長を伴う流れは，12時間もしくは24時間周期で変動する ことがわかる. また，この両者のパワースペクトルの ピーク值を比較すると，12時間よりも24時間周期の方が 大きくなることから, 津軽海峡の流れは24時間周期の変 動成分による流れに強く影響されていると考えられる. なお，この結果は，中層及び下層においても同様になる ことを確認している.

図-4(a) は，前出の図-2(d) で示した実測潮位におい て日本海側から太平洋側を差し引いた潮位差と各層にお ける北方流速と東方流速の合成流速との相互相関をとっ たものを示す。各層の合成流速は潮位差に対して3時間 ほど遅れて応答していることがわかる，図-4(b) は，こ 


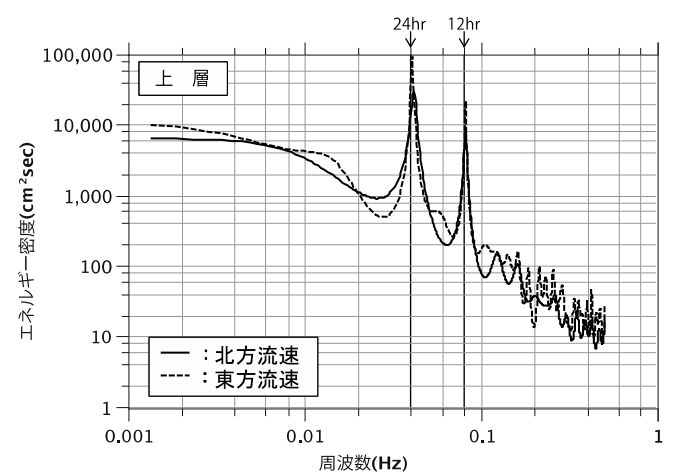

図-3 上層に扔ける北方及び東方流速のスペクトル解析結果

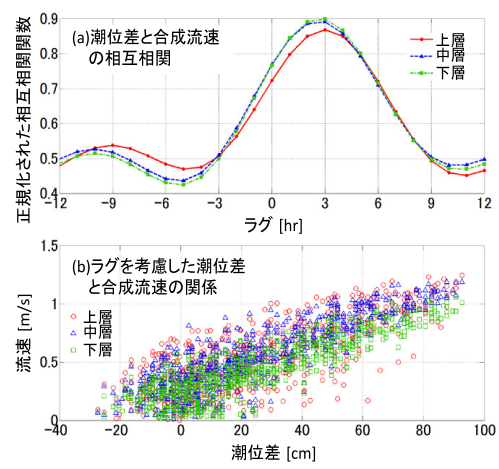

図-4 潮位差と合成流速の関係
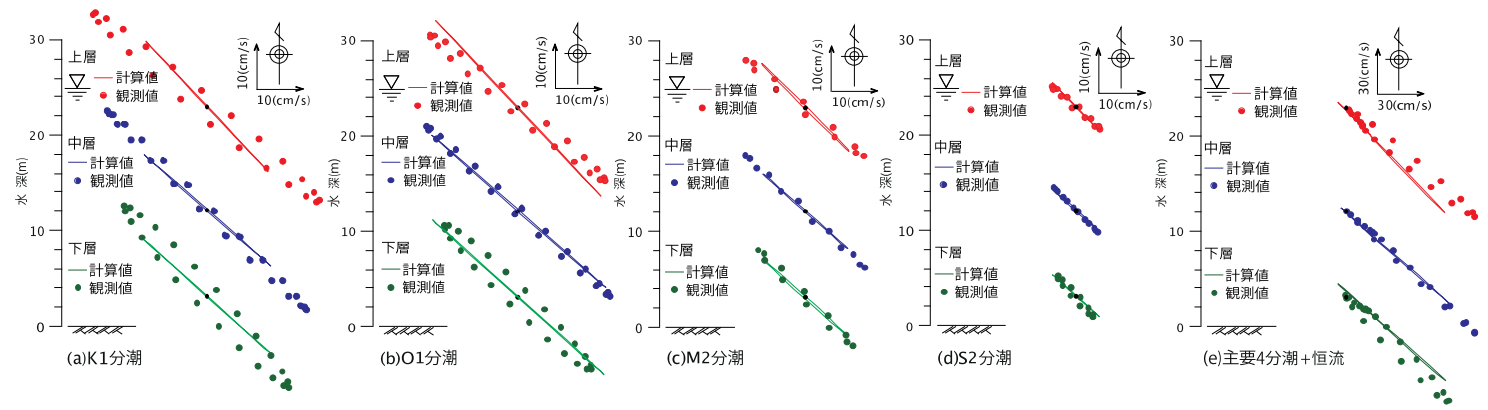

図-5 各層における主要4分潮及びそれらと恒流を合成した潮流棈円

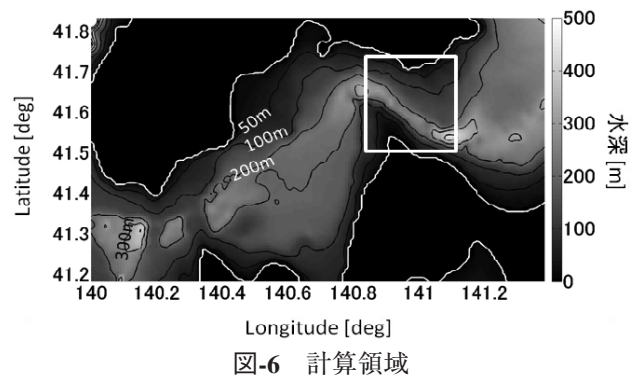

の3時間遅れを考慮した潮位差と各層の合成流速の関倸 を示す。これより，太平洋側よりも日本海側の潮位が高 くなり潮位差が大きくなるとき，合成流速は全層ともに 大きくなる。このことから，日本海側と太平洋側で生じ る潮位差が津軽海峡の各層で生じる流速に及ぼす影響は 大きいものと推察される.

図-5は各層で得られた観測流速に調和分解を施し，主 要4分潮及びそれらと恒流を合成した潮流楕円を示す. 図中（a）（d）中の@印で示す観測值による主要4分潮 の潮流楕円はいずれも, 北西一南東方向に長軸を有して いる．各分潮に扮ける潮流棈円の軌道長半径を比較する と，半日周期であるM 2及びS2分潮よりも日周期である K1及び01分潮の方が大きくなり，これは前述したスぺ クトル解析で得た傾向に一致する。これょり観測期間中 における津軽海峡の流れは, 北西-南東方向に長軸を有す
表-2 計算グリッドの諸元

\begin{tabular}{l|l}
\hline 計算領域 & $\begin{array}{l}\text { 北緯 } 41^{\circ} 11^{\prime} 00^{\prime \prime} \sim \text { 北緯 } 41^{\circ} 50^{\prime} 00^{\prime \prime} \\
\text { 東経 } 140^{\circ} 00^{\prime} 00^{\prime \prime} \sim \text { 東経 } 141^{\circ} 23^{\prime} 00^{\prime \prime}\end{array}$ \\
\hline グリッド間隔 & $\begin{array}{l}30 " \times 20^{\prime \prime} \times 10.0-15.0 \mathrm{~m} \\
(\text { Lon. } \times \text { Lat. } \times \text { Vert. })\end{array}$ \\
\hline 時間ステップ & 10 秒 \\
\hline
\end{tabular}

る日周潮による潮流の影響を強く受けることがわかる. また，この観測期間中に得られた恒流成分は全層ともに 南東方向に作用する，そのため，図中（e）に示す主要4 分潮と恒流を合成した潮流楕円において，各分潮による 北西方向の潮流は南東方向の恒流により打ち消され，そ の重心が原点から南東方向にシフトした結果, 南東方向 に向かって周期的に消長する流れが形成されるものと推 察される。

\section{M IT gcmによる津軽海峡の流況解析}

\section{（1）計算方法及び条件}

観測期間における津軽海峡全域の流況特性を把握する ため，圧縮性流体に対するN avier-Stokesの式を有限体積 法により解法する非静水圧三次元流れモデルMIT g c r を 用いて再現計算を行った．計算領域は図-6に示す津軽海 峡全域を包含する海域とし，計算グリッドの諸元を表-2 に示す，計算は猿渡ら（2013）が行った方法と同様の方 針のもと，日本海側及び太平洋側の境界には，海面高度 


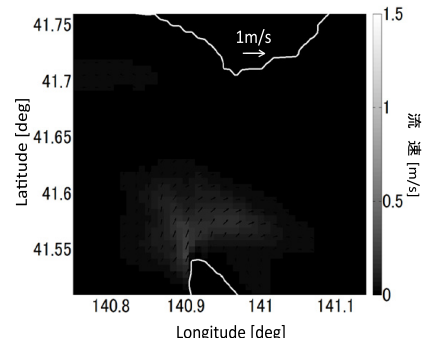

(a) 潮流のみ (case1)

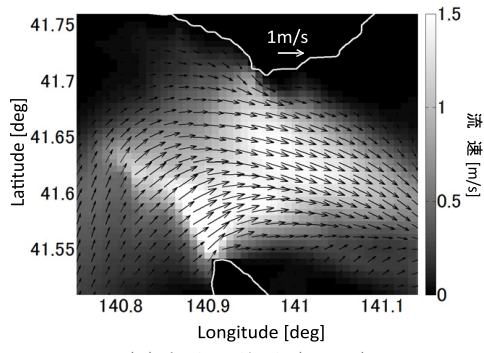

(b) 潮流 + 海流 (case2)

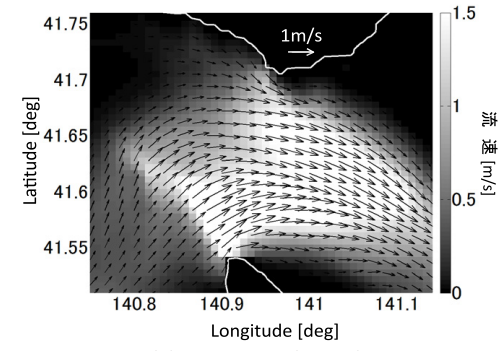

(c) 海流のみ (case3)

図-7 各ケースの上層における恒流流速ベクトル分布
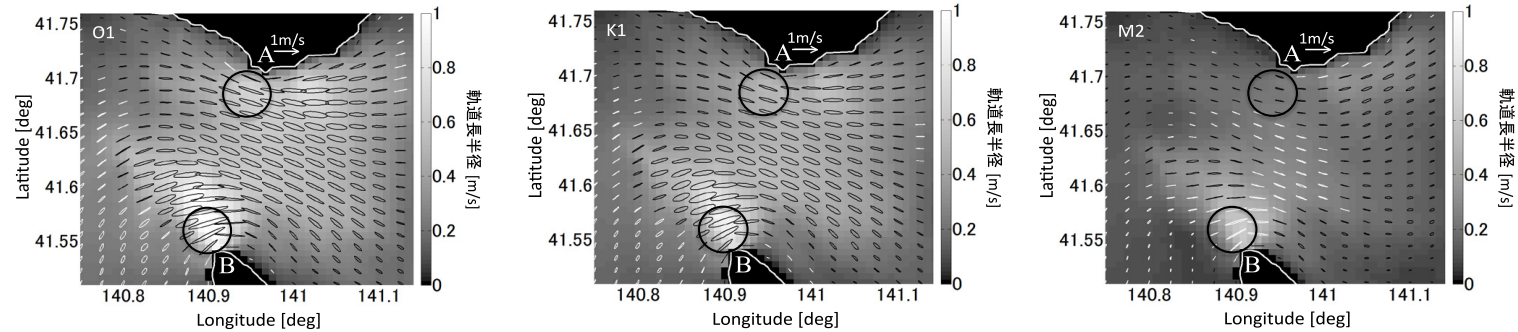

図-8 潮流のみ考虑した場合 (case1)の上層におけるK 1, 01, M 2分潮の潮流楕円分布 (黒 : 時計方向, 白 : 反時計方向)
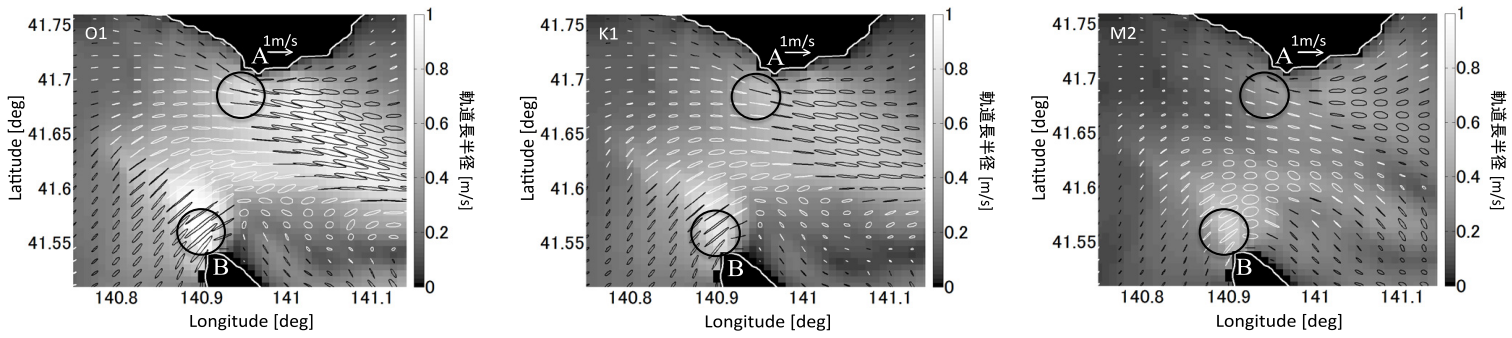

図-9 潮流と海流を考虑した場合 (case2)の上層におけるK 1, 01，Ｍ2分潮の潮流楕円分布(黒：時計方向, 白：反時計方向）

測定衛星TOPEX/Poseidonの測定データによる調和解析と デー夕同化を組み合わせることにより得られた全球海洋 潮汐モデルTPX07.2の解のうち主要8分潮（M2，S2，N2， K2，K1，01，P1，Q1）の潮流流速を補間して与えている. また, 海流流速は海洋研究開発機構 (JAMSTEC) が短期 気候変動応用予測研究プログラムの中で計算された再解 析データFRA-JCOPE2を流入境界条件として入力してい る. 計算期間は, 現地観測と同一とし, 潮流のみを計算 したcase1，潮流と海流を同時に計算したcase2，海流の みを対象としたcase3の3ケースを計算対象とした.

前出の図-5中に示す実線は, 潮流と海流を同時に計算 したcase2による主要4分潮及びそれらと恒流を合成した 潮流楕円の計算值を示す。これより，本計算による潮流 楕円は, K1分潮においてやや過小評価になるものの, 各 分潮及びそれらと恒流を合成した現地観測の潮流楕円 を，ともに概ね良好な結果で再現する。

\section{（2）津軽海峡東部海域の流況特性}

図-7は前出の図-6中の $\square て ゙$ 囲んだ津軽海峡東部海域に
おける恒流流速ベクトル分布を示す. 図中（a）に示す 潮流のみ考慮したcase1の場合, 流速は微小であり, 潮汐 残差流として津軽海峡東部海域を恒常的に流れる成分は 小さいといえる。 これに対し, 眓中（b）の潮流と海流 を考慮したcase2では, 日本海側から北東方向に流入し, 下北半島を回り达み, 太平洋側に向かって南東方向に流 向を転じる流れが生じ, caselの場合とは異なる結果とな る。一方, 図中（c）に示す海流のみを考慮したcase3と 眓中（b）を比較すると，両者による流れは，流速・流 向ともにほぼ同様な分布となる。このことから, 観測期 間中に津軽海峡東部海域を流れる恒流は, 海流による影 響が大きいものと考えられる。

図-8及び9は，潮流のみを考慮したcase1及び潮流と海 流を考慮したcase2に扔ける主要4分潮のうち, 流況観測 の結果から流れに与える影響が大きかったK 1，01，M2分 潮の潮流楕円分布をそれぞれ表示したものである. 津軽 海峡東部海域の中でも流れが速くなる汐首岬沿岸海域 （図中Aの○）と下北半島沿岸海域（図中Bの○）に着目 
すると，潮流と海流を考虑した場合，汐首岬側では海流 の影響を受け，潮流のみを考慮した場合に比して，潮流 楕円の長軸方向自体に大きな変化はないものの, 軌道長 半径が海流の流れる方向に伸長し, 各分潮の潮流流速を 増加させている。, 一方, 下北半島側では, 潮流と海流を 考慮したことにより，汐首岬側よりも軌道長半径が更に 大きく伸長しているが, それに加えて潮流楕円長軸の向 きも変化し，各分潮の流向にも影響が及ぶ．以上の上う に津軽海峡東部海域を恒流として流れる海流は, 各分潮 における潮流流速や流向に大きな影響を与えていること がわかる.

\section{（4）津軽海峡東部海域の流れエネルギー賦存量}

図-10はcase2の計算期間中の最大流速を用いて, 観測 期間中の単位断面積あたりの最大流れエネルギー密度 $\mathrm{D}\left[\mathrm{W} / \mathrm{m}^{2}\right]$ を次式によって求めた分布を示す.

$$
D=\frac{1}{2} \rho\left|U^{3}\right|
$$

ここに, $\rho$ は海水の密度であり， $1030 \mathrm{~kg} / \mathrm{m}^{3}$ とした，春期 において津軽海峡が有する最大でのエネルギーポテン シャルを把握するため，Uは計算期間中で最大となる北 方及び東方流速の合成流速を水深平均した值を示す，発 電装置を設置する水深を勘案すると, 下北半島沿岸部及 び汐首岬沿岸部では, 潮流に海流が加わることにより, 浅海域でも比較的大きな流速が発生するため, 最大流れ エネルギー密度は両沿岸部で高く分布する。この最大流 れエネルギー密度のみに着目して, 潮流・海流発電を行 う場合の適地を選定すれば, 津軽海峡東部海域では, 工 ネルギー密度の最も高い下北半島沿岸部となる。しかし， 前述したように下北半島沿岸海域では, 恒流として流れ る海流によって潮流流速に加え，その流向にも大きな影 響が及ぶことを考慮すると，年間通じた流況観測により 季節的な海流の変動とそれらが潮流流速・流向に与える 影響に十分配虑する必要があるものと考えられる.

\section{4. 結 論}

本研究で得られた結論を要約すると, 以下のと㧍りで ある。

（1）観測期間中の津軽海峡の流れは，北西 - 南東方向に 長軸を有する日周期による潮流の影響を強く受けると 同時に, 南東方向に向かう恒流が加わることで, 南東 方向に向かって周期的に消長する流況特性を有してい る.

（2）MIT g cmによる潮流と海流を考慮した津軽海峡の流 れ計算の結果，本計算による潮流楕円は，K1分潮にお いてやや過小評価になるものの，各分潮およびそれら と恒流を合成した現地観測の潮流楕円を概ね良好な結 果で再現することができる.

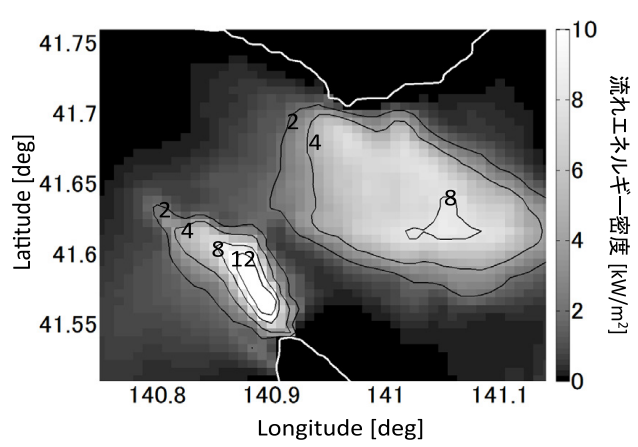

図-10 case2(潮流+海流)の最大流れエネルギー密度分布

（3）津軽海峡東部海域において，最大流れエネルギー密 度のみに着目して潮流・海流発電を行う場合の適地を 選定すれば，最も高くエネルギーが分布する下北半島 沿岸部となる。しかし, 当該海域は海流によって潮流 流速に加え，その流向にも大きな影響が及ぶことを考 慮すると, 季節的な海流の変動とそれらが潮流流速・ 流向に与える影響に十分配虑する必要がある.

今後は, 夏期〜秋期に渡る津軽海峡の流況観測から, 季節的な流れ特性について把握するとともに，年間通じ た津軽海峡のエネルギー賦存量の平面分布特性を明らか にする所存である。

謝辞：現地観測を行うにあたり，函館市の本吉勲氏，並 びに，同市の溝江隆紀氏には，多大なご協力を得た。こ こに感謝の意を表す.

\section{参 考 文 献}

井内国光・中村孝幸・安井 孝·二宮一成 (2011)：来島海峡 周辺海域における潮流エネルギー賦存量の推定, 土木学 会論文集B3（海洋開発）、vol.67, N o.2, pp.I_1901-I_1905.

小牧祐幸・ 城徽・城本一義・仁科文子.中村啓彦・広瀬 直毅（2013）：海流発電適地選定のためのトカラ海峡周辺 海域に扔ける黒潮潮差, 土木学会論文集B3 (海洋開発), vol.69, N o.2, pp.I_109-I_113.

猿渡亜由未・田島 悠 (2012)：潮流エネルギーの平面及び鉛 直分布の特徵，土木学会論文集（海岸工学），B2，vol.68， No.2, pp.I_1271-I_1275.

猿渡車由未·田島 悠・米子佳広・齊藤 樹 (2013)：津軽海 峡の潮流エネルギーリソースに海流が与える影響，土木 学会論文集B2 (海岸工学), vol.69, N o.2, pp.I_1296-I_1300. 独立行政法人新エネルギー・産業技術総合開発機構 (2010): 平成22年度成果報告書 風力等自然エネルギー技術研究開 発/洋上風力発電等技術研究開発/海洋エネルギーポテン シャル把握に関する業務, pp.23-26.

M arshall, J., C., Hill, L.Perelman and A.A dcroft (1997a): Hydrostatic, quasi- hydrostatic, and nonhydrostatic ocean modeling, J. G eophy. Res. Oceans, 102, C3, pp.5733-5752.

M arshall, J. A . A dcroft, C. Hill, L. Perelman and C. Heisy (1996b): A finite-volume, incompressible $\mathrm{Navier}$ Stokes model for studies of the ocean on parallel computers, J. Geophys. Res. Oceans, 102, C3, pp.5753-5756. 